\title{
Efect of Selected Elements on the Microstructure of Secondary Al-Si Alloys
}

Lukáš Richtárech, Dana Bolibruchová

Department of Technological Engineering, Faculty of Mechanical Engineering, University of Žilina, Univerzitná 1, 010 26, Slovak Republic, Email: lukas.richtarech@fstroj.uniza.sk

This paper deals with influence on segregation of iron based phases on the secondary alloy AlSi7Mg0.3 microstructure by chrome and nickel. It is impossible to remove iron from melt by standard operations, but it is possible to eliminate its negative influence by addition some other elements that affect the segregation of intermetallics in less harmful type. Realization of experiments and results of analysis shows new view on solubility of iron based phases during melt preparation with higher iron content. By experimental work were as an iron correctors used three different amounts of AICr20 and AINi20 master alloys. Addition of these master alloys had a significant impact on the shape of intermetallic phases and mechanical properties.

Keywords: secondary AlSi7Mg0.3 alloys, intermetallic phases, iron correctors, AlCr20, AlNi20

\section{Acknowledgment}

This work was created in framework of the grant project VEGA ̌̌. 1/0363/13. The authors would like to thank the Grant Agency for support.

\section{References}

[1] HURTAlOVÁ, L., TILlOVÁ, E. (2013). Elimination of the negative effect of Fe-rich intermetallic phases in secondary (recycled) aluminium cast alloy. In Manufacturing Technology, Vol. 13, No. 1, p. 44-50

[2] ĎURNIKOVÁ, E., TILLOVÁ, E. (2011). Phase and structure characteristics of recycled AlZn10Si8Mg cast alloy., In Manufacturing Technology: Journal for science research and production, Vol. 11, No. 11, pp. 70-76

[3] BOLIBRUCHOVÁ, D., RICHTÁRECH, L. (2013). Effect of adding iron to the AlSi7Mg0.3 (EN AC 42100 , A356) alloy. In Manufacturing Technology : Journal for science research and production, Vol. 13, No. 3, p. 276 281

[4] BRU゚NA, M., KUCHARČÍK, L., SLÁDEK, A. (2013). Complex evaluation of porosity in A356 aluminium alloy using advanced porosity module. In Manufacturing Technology : Journal for science research and production, Vol. 13 , No. 1, p. 26-30

[5] MICHALCOVÁ, A., VOJTĚCH, D. (2012). Structure of rapidly solidified aluminium alloys. In Manufacturing Technology: Journal for science research and production. ISSN 1213-2489. vol. 12, p.166-169

[6] LIPIŃSKI, T. (2011). Use Properties of the AlSi9Mg Alloy With Exothermical Modifier. In Manufacturing Technology: Journal for science research and production. ISSN 1213-2489. vol. 11, p. 44-49

[7] EPEREJEŠI, L'. - MALIK, J. - EPEREJEŠI, Š - FECKO, D. (2013) Influence of returningmaterial on porosity of diecasting. In Manufacturing Technology: Journal for science research and production, Vol.13,No.1, pp.36-39

[8] PASTIRČÁK, R., KRIVOŠ, E. (2013). Effect of opening material granularity on the mould properties and the quality of casting made by patternless process technology. In Manufacturing Technology: Journal for science research and production. Vol.13, no.1 (2013), p. 92-97, ISSN 1213-2489

[9] TAYLOR, J.A. (2004). The effect of iron in Al-Si casting alloys, 35th Australian Foundry Institute National Conference, Adelaide, South Australia, pp. 148-157.

[10] SAMUEL, A.M., SAMUEL, F. H., DOTY, H. W. (1996). Observation on the formation of $\beta$ - Al5FeSi phase in 319 type Al-Si alloys. Journal of Materials Science, Vol. 31, pp. 5529-5539

[11] GRZINCIC, M., LUKÁČ, I. (2014). Identification of Intermetallic Phases in the Alloy AlSi6Cu4. In Manufacturing Technology: Journal for science research and production. Vol. 14, No. 2 (2014), p. 160-166, ISSN 1213-2489 